\title{
UJI ANTIMITOSIS EKSTRAK ETANOL BUAH MERAH (Pandanus conoideus Lam) DENGAN METODE PENGHAMBATAN PEMBELAHAN SEL TELUR Tripneustes gratilla Linn TERFERTILISASI
}

\author{
Sitti Amirah, Heriyanto Beddu \\ Fakultas Farmasi Universitas Muslim Indonesia \\ Email : amirahsitti85@gmail.com
}

\begin{abstract}
The research concerning antimitotic assay of "Buah Merah" (Pandanus conoideus Lam) ethanol extract using sea urchin Tripneustes gratilla Linn eggs cleavage inhibition method had been conducted. The aim of this study was to determine the antimitotic effect of buahMerah ethanol extract in to inhibit cell cleavage of fertilized sea urchin eggs. Buah Merah ethanol extract was made in to 5 concentration there was $0,001 \mu \mathrm{g} / \mathrm{ml}, 0,01 \mu \mathrm{g} / \mathrm{ml}, 0,1 \mu \mathrm{g} / \mathrm{ml}, 1 \mu \mathrm{g} / \mathrm{ml}$ and $10 \mu \mathrm{g} / \mathrm{ml}$ with vincristine as the compared. Quantivication of cell cleavage was performed visually under the light microscopy by counting the number of cleaveaged and non cleaveaged embryos after an incubation time of \pm 2 hours. If $80-100 \%$ inhibition of cleavage $\left(I C_{80-100}\right)$ occurs at $\leq 16 \mathrm{mg} / \mathrm{ml}$, the compound is considered to be active as antimitotic. The result of this research showed that $I C_{80}$ value of "BuahMerah" ethanol extract was $0,026 \mathrm{mg} / \mathrm{ml}$. According to the value ethanol extract was categorized active as antimitotic, although their potency lower than vincristin which can inhibit $80 \%$ of fertilized sea urchin eggs at $2,789 \times 10^{-4} \mathrm{mg} / \mathrm{ml}$.
\end{abstract}

Key words: Pandanus conoideus Lam, Antimitotic, Tripneustes gratilla Linn.

\section{PENDAHULUAN}

Indonesia dikenal secara luas memiliki keanekaragaman hayati terbesar di dunia. Di wilayah Indonesia terdapat sekitar 30.000 jenis tumbuhan dan 7.000 diantaranya berpotensi sebagai obat. Saat ini banyak sekali bahan alam yang digunakan sebagai obat alternatif untuk mengobati penyakit kanker.

Kanker adalah penyakit yang tidak mengenal status sosial dan dapat menyerang siapa saja. Kanker merupakan penyakit atau kelainan pada tubuh sebagai akibat dari sel-sel tubuh yang tumbuh dan berkembang secara abnormal, diluar kewajaran dengan pertumbuhan yang sangat cepat, sehingga tidak dapat dikendalikan oleh tubuh.

Salah satu jenis tanaman yang dimanfaatkan oleh masyarakat papua sebagai bahan obat adalah buah 
merah (Pandanus conoideus Lam (Budi dan Paimin, 2005).

\section{METODE PENELITIAN}

Alat dan Bahan, Alat dan bahan yang akan digunakan disiapkan sesuai dengan kebutuhan penelitian.

\section{A. Prosedur Penelitian}

\section{Penyiapan Sampel}

Bahan penelitian berupa
tumbuhan buah merah
(Pandanus conoideus Lam)
Pengambilan tumbuhan buah
merah (Pandanus conoideus
Lam) dilakukan pada pagi hari
sekitar pukul 10.00 WITA,
dengan cara mengambil
buahnya kemudian dilakukan
pencucian dengan air mengalir.
Buah yang telah bersih dikering
dengan cara di angin-anginkan
pada tempat yang tidak
terpapar sinar matahari
langsung dan siap untuk
diekstraksi.

Simplisia buah merah (Pandanus conoideus Lam) sebanyak $300 \quad$ gram dimasukkan dalam wadah meserasi, tambahkan etanol hingga simplisia tersebut terendam, dibiarkan selama 5 hari dalam bejana tertutup dan terlindung dari cahaya sambil berulang-ulang diaduk. Setelah 5 hari simplisia di saring dan ampasnya direndam lagi dengan cairan penyari yang baru. Hal ini dilakukan sebanyak 3 kali. Hasil penyarian yang didapat kemudian dikumpulkan dan diuapkan dengan menggunakan hair dryer dan kipas angin hingga diperoleh ekstrak etanol yang kental.

\section{B. Uji Antimitosis}

\section{Pemilihan dan Pemiliharaan Hewan Uji}

Hewan uji yang digunakan dalam penelitian ini adalah jenis Tripneustes gratilla Linn. Dimana Tripneustes gratilla Linn ini dipelihara dalam aquarium yang berisi air laut bersih yang dilengkapi dengan aerator dan diadaptasi selama 24 jam.

2. Penyiapan dan Pembuatan Bahan

\section{a. Pembuatan larutan $\mathrm{KCl} \mathbf{1 0}$ $\% \mathbf{b} / \mathbf{v}$ \\ Larutan yang dibuat sebanyak 10 gram $\mathrm{KCl}$, kemudian dimasukkan kedalam labu tentukur 100 $\mathrm{ml}$ kemudian ditambahkan air suling sedikit demi}


sedikit, sambil dikocok dan dicukupkan volumenya sampai $100 \mathrm{ml}$.

b. Penyiapan air laut bersih untuk media

Air laut bersin yang akan digunakan sebagai air media dan untuk membersihkan media uji dibuat dengan cara menyaring dengan menggunakan kertas saring Whatman nomor 1 , setelah itu disterilkan di autoklaf sehingga bebas dari protozoa.

\section{c. Pembuatan pembanding}

Pembanding (Kontrol positif )yang digunakan yaitu obat vinkristin dengan kosentrasi $0,01 \mu \mathrm{g} / \mathrm{ml}, \quad 0,1$ $\mu \mathrm{g} / \mathrm{ml}$, dan $1 \mu \mathrm{g} / \mathrm{ml}$. Vinkristin $1 \mathrm{mg} / \mathrm{ml}$ dipipet $100 \mu$ dilarutkan dalam air laut dan dicukupkan volumenya $1 \mathrm{ml}$ hingga diperoleh kosentrasi 100 $\mu \mathrm{g} / \mathrm{ml}$ sebagai larutan stok.

Untuk membuat konsentrasi $1 \mu \mathrm{g} / \mathrm{ml}$ maka dibuat terlebih dahulu konsentrasi $10 \mu \mathrm{g} / \mathrm{ml}$, dengan cara dipipet sebanyak $1 \mu \mathrm{l}$ dari larutan stok ke dalam vial, lalu ditambahkan $899 \mu$ air laut bebas protozoa.

Untuk membuat kosentrasi $1 \mu \mathrm{g} / \mathrm{ml}$ maka dipipet $1 \mu \mathrm{l}$ dari larutan konsentrasi $10 \mu \mathrm{g} / \mathrm{ml}$ ke dalam vial, lalu ditambahkan $899 \mu \mathrm{l}$ air laut bebas protozoa dibuat sebanyak 2 kali, salah satunya akan dijadikan larutan stok untuk membuat konsentrasi 0,1 $\mu \mathrm{g} / \mathrm{ml}$, untuk konsentrasi 0,1 $\mu \mathrm{g} / \mathrm{ml}$ dipipet $1 \mu \mathrm{l}$ dari larutan stok $1 \mu \mathrm{g} / \mathrm{ml}$ dan ditambahkan $899 \mu \mathrm{l}$ air laut bebas protozoa, dibuat sebanyak 2 kali, salah satunya akan dijadikan larutan stok untuk membuat konsentrasi $\quad 0,01 \mu \mathrm{gg} / \mathrm{ml}$, untuk membuat konsentrasi $0,01 \mu \mathrm{g} / \mathrm{ml}$ maka dipipet $1 \mu \mathrm{l}$ dari larutan stok konsentrasi $0,1 \mu \mathrm{g} / \mathrm{ml}$ lalu ditambahkan $899 \mu \mathrm{l}$ air laut bebas protozoa.

\section{d. Pembuatan sediaan uji}

$$
\begin{aligned}
& \text { Sampel ekstrak } \\
& \text { etanol buah merah } \\
& \text { (Pandanu sconoideus Lam) } \\
& \text { ditimbang sebanyak } 10 \mathrm{mg}
\end{aligned}
$$




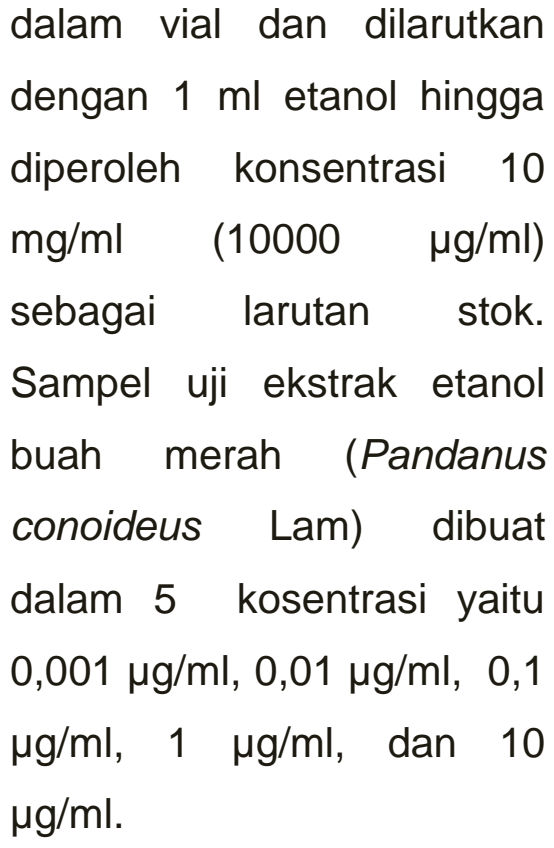

Untuk membuat konsentrasi $10 \mu \mathrm{g} / \mathrm{ml}$ dibuat sebanyak dua kali, dipipet 1 $\mu \mathrm{l}$ dari larutan stok ke dalam vial, lalu ditambahkan $899 \mu \mathrm{l}$ air laut bebas protozoa, untuk konsentrasi $1 \mu \mathrm{g} / \mathrm{ml}$ dibuat sebanyak dua kali, dipipet $1 \mu$ dari larutan sampel $10 \mu \mathrm{g} / \mathrm{ml}$ dan ditambahkan $899 \mu \mathrm{l}$ air lautbebas protozoa, salah satunya akan dijadikan larutan stok sampel untuk membuat konsentrasi 0,1 $\mu \mathrm{g} / \mathrm{ml}$, untuk membuat konsentrasi $0,1 \mu \mathrm{g} / \mathrm{ml}$ maka dipipet $1 \mu \mathrm{l}$ larutan stok sampel $1 \mu \mathrm{g} / \mathrm{ml}$ lalu ditambahkan $899 \mu$ l air laut bebas protozoa, dibuat sebanyak 2 kali yang salah satunya akan dijadikan larutan stok sampel untuk membuat konsentrasi 0,01 $\mu \mathrm{g} / \mathrm{ml}$, untuk membuat konsentrasi $0,01 \mu \mathrm{g} / \mathrm{ml}$ maka dipipet $1 \mu$ larutan stok sampel dari konsentrasi 0,1 $\mu \mathrm{g} / \mathrm{ml}$ lalu ditambahkan 899 $\mu \mathrm{l}$ air laut bebas protozoa, dibuat sebanyak 2 kali yang salah satunya akan dijadikan larutan stok sampel untuk membuat konsentrasi 0,001 $\mu \mathrm{g} / \mathrm{ml}$, untuk membuat konsentrasi $\quad 0,001 \mu \mathrm{gg} / \mathrm{ml}$ maka dipipet $1 \mu \mathrm{l}$ larutan stok sampel dari konsentrasi $0,01 \mu \mathrm{g} / \mathrm{ml}$ lalu ditambahkan $899 \mu \mathrm{l}$ air lautbebas protozoa.

\section{Penyiapan Sperma dan Ovum Tripneustes gratilla Linn}

Ovum yang fertil umumnya berbentuk bola, berwarna orange keemasan (agak terang), membran vitelinnya tidak mengalami kerusakan, 5-10 menit setelah bertemu dengan sperma akan terbuahi. Selain itu terjadinya fertilisasi juga dipengaruhi oleh keaktifan pergerakan sperma Tripneustes gratilla Linn. 
Tripneustes gratilla Linn jantan dan betina diinduksi dengan menyuntikkan $1 \mathrm{ml} \mathrm{KCl}$ $10 \%$ ke dalam bagian gonad. Sperma yang berwarna putih susu dan sel telur yang berwarna kuning keemasan ditampung pada gelas kimia yang berbeda dan berisi air laut bebas protozoa. Setelah itu dimasukkan pada lemari pendingin. Fertilisasi dilakukan dengan cara $1 \mathrm{ml}$ sperma dan 4 $\mathrm{ml}$ sel telur difertilisasikan dalam gelas kimia yang berisi $50 \mathrm{ml}$ air laut bebas protozoa.

\section{Pengujian Sampel}

Setelah sampel uji ekstrak etanol buah merah (Pandanus conoideus Lam) ditambahkan dengan air laut bebas protozoa. Sampel dipanaskan dengan menggunakan tangas air padasuhu $60-80^{\circ} \mathrm{C}$ selama $15-$ 20 menit untuk menguapkan pelarut etanol yang terdapat dalam sampel uji, setelah dingin semua sampel uji dipindahkan kedalam tabung eppendorf dan ditambahkan masing-masing $100 \mu \mathrm{l}$ cairan berisi zigot yang diperoleh setelah 5-10 menit terjadinya fertilisasi.
Kontrol positif yang digunakan yaitu obat vinkristin dengan kosentrasi $0,01 \mu \mathrm{g} / \mathrm{ml}$, $0,1 \mu \mathrm{g} / \mathrm{ml}$, dan $1 \mu \mathrm{g} / \mathrm{ml}$. Setelah di tambahkan dengan air laut bebas protozoa, kemudian dipindahkan ke dalam tabung eppendorf dan ditambahkan masing-masing $100 \mu \mathrm{l}$ cairan berisi zigot.

Kontrol negatif yang digunakan yaitu air laut bebas protozoa sebanyak $900 \mu \mathrm{l}$ ditambahkan $100 \mu \mathrm{l}$ zigot dan kontrol pelarut yaitu etanol sebanyak $10 \mu \mathrm{l}$ ditambahkan $890 \mu \mathrm{l}$ air laut bebas protozoa, lalu diuapkan pelarutnya (etanol) lalu ditambahkan ditambahkan $100 \quad \mu \mathrm{l}$ cairan berisi zigot.

Dilakukan replikasi 3 kali untuk tiap sampel uji, kontrol dan pembanding. Selanjutnya disimpan pada suhu $15-20{ }^{\circ} \mathrm{C}$ dengan diselingi pengocokan.

Pengamatan sel yang membelah dilakukan setelah 2 jam inkubasi di bawah mikroskop dengan mengambil gambar setiap sampel. Pengamatan dilakukan dengan menghitung jumlah sel yang 
Uji Antimitosis Ekstrak Etanol Buah Merah Dengan Metode Penghambatan Pembelahan Sel

terhambat dan total sel untuk

dihitung sebagai $\mathrm{IC}_{50}$ dan $\mathrm{IC}_{80}$.

\section{HASIL PENELITIAN}

Tabel 1. Hasil Pengamatan Penghambatan Pembelahan Sel Telur Tripneustes gratilla Linn ekstrak etanol buah merah (Pandanus conoideus Lam)

\begin{tabular}{|c|c|c|c|c|c|c|}
\hline Sampel & $\begin{array}{l}\text { Konsentrasi } \\
(\mu \mathrm{g} / \mathrm{ml})\end{array}$ & Replikasi & $\begin{array}{l}\text { Sel yang } \\
\text { membelah }\end{array}$ & $\begin{array}{l}\text { Sel yang } \\
\text { dihambat }\end{array}$ & $\begin{array}{l}\text { Total } \\
\text { sel }\end{array}$ & $\begin{array}{c}\% \\
\begin{array}{c}\text { Penghambatan } \\
\text { sel }\end{array}\end{array}$ \\
\hline \multirow{15}{*}{ 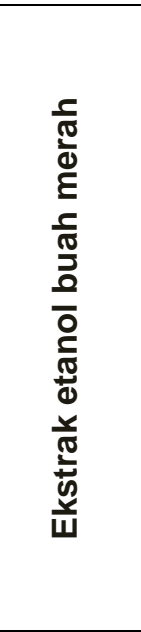 } & \multirow{3}{*}{0,001} & 1 & 228 & 143 & 371 & 38,54 \\
\hline & & 2 & 33 & 24 & 57 & 42,11 \\
\hline & & 3 & 208 & 246 & 454 & 54,19 \\
\hline & \multirow{3}{*}{0,01} & 1 & 70 & 86 & 156 & 55,13 \\
\hline & & 2 & 108 & 142 & 250 & 56,8 \\
\hline & & 3 & 96 & 130 & 226 & 57,52 \\
\hline & \multirow{3}{*}{0,1} & 1 & 103 & 245 & 348 & 70,40 \\
\hline & & 2 & 151 & 369 & 520 & 70,96 \\
\hline & & 3 & 113 & 286 & 399 & 71,68 \\
\hline & \multirow{3}{*}{1} & 1 & 55 & 217 & 272 & 79,78 \\
\hline & & 2 & 67 & 263 & 330 & 79,69 \\
\hline & & 3 & 56 & 181 & 237 & 76,38 \\
\hline & \multirow{3}{*}{10} & 1 & 67 & 298 & 365 & 81,64 \\
\hline & & 2 & 54 & 257 & 311 & 82,64 \\
\hline & & 3 & 45 & 269 & 314 & 85,67 \\
\hline
\end{tabular}

Tabel 2. Hasil pengamatan penghambatan pembelahan sel telur Tripneustes gratilla Linn oleh Vinkristin (kontrol positif).

\begin{tabular}{|c|c|c|c|c|c|c|}
\hline Sampel & $\begin{array}{l}\text { Konsentrasi } \\
(\mu \mathrm{g} / \mathrm{ml})\end{array}$ & Replikasi & $\begin{array}{l}\text { Sel yang } \\
\text { membelah }\end{array}$ & $\begin{array}{l}\text { Sel yang } \\
\text { dihambat }\end{array}$ & Total sel & $\%$ \\
\hline \multirow{9}{*}{ 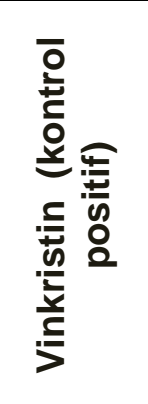 } & \multirow{3}{*}{0,01} & 1 & 23 & 47 & 70 & 67,143 \\
\hline & & 2 & 28 & 67 & 95 & 70,526 \\
\hline & & 3 & 28 & 70 & 98 & 71,429 \\
\hline & \multirow{3}{*}{0,1} & 1 & 25 & 79 & 104 & 75,962 \\
\hline & & 2 & 7 & 35 & 42 & 83,333 \\
\hline & & 3 & 6 & 35 & 41 & 85,366 \\
\hline & \multirow{3}{*}{1} & 1 & 5 & 32 & 37 & 86,480 \\
\hline & & 2 & 5 & 40 & 45 & 88,889 \\
\hline & & 3 & 5 & 63 & 68 & 92,647 \\
\hline
\end{tabular}

Tabel 3. Hasil Pengamatan Penghambatan Pembelahan Sel Telur Tripneustes gratilla Linn oleh air laut (kontrol negatif) dan pelarut etanol (kontrol pelarut).

\begin{tabular}{cccccc}
\hline Sampel & Replikasi & $\begin{array}{c}\text { Sel yang } \\
\text { membelah }\end{array}$ & $\begin{array}{c}\text { Sel yang } \\
\text { dihambat }\end{array}$ & Total sel & $\%$ \\
\hline Air laut & 1 & 127 & 5 & 132 & 3,79 \\
(kontrol negatif) & 2 & 130 & 7 & 137 & 5,12 \\
& 3 & 118 & 8 & 126 & 6,35 \\
\hline Air laut Etanol & 1 & 58 & 5 & 63 & 7,93 \\
(Kontrol pelarut) & 2 & 62 & 6 & 68 & 8,82 \\
& 3 & 48 & 5 & 48 & 9,43 \\
\hline
\end{tabular}


PEMBAHASAN

Hasil dari penelitian ini menunjukan bahwa ekstrak etanol buah merah (Pandanus conoideus Lam)pada konsentrasi $0,001 \mu \mathrm{g} / \mathrm{ml}$, $0,01 \mu \mathrm{g} / \mathrm{ml}, 0,1 \mu \mathrm{g} / \mathrm{ml}, 1 \mu \mathrm{g} / \mathrm{ml}$, dan 10 $\mu \mathrm{g} / \mathrm{ml}$ dapat menghambat pembelahan sel telur Tripneustes gratilla Linn dengan penghambatan rata- rata sebesar 36,22\%, 47,75\%, 62,28\%, $69,99 \%$, dan 74,59\%. Data tersebut memperlihatkan bahwa efek antimitosis akan menurun pada konsentrasi yang lebih rendah hal ini disebabkan karena semakin kecil konsentrasi ekstrak yang digunakan maka semakin kecil pula kandungan senyawa kimia yang menghambat pembelahan zigot Tripneustes gratilla Linn, hal tersebut seperti halnya pada Vinkristin sebagai pembanding dengan konsentrasi $0,01 \mu \mathrm{g} / \mathrm{ml}, 0,1 \mu \mathrm{g} / \mathrm{ml}, 1$ $\mu \mathrm{g} / \mathrm{ml}$ dengan penghambatan ratarata sebesar, 64,613\%, 76,467\% dan $84,249 \%$.

Dari data diatas menunjukkan bahwa persentase penghambatan sel telur Tripneustes gratilla Linn yang terbesar yaitu pada konsentrasi 10 $\mu \mathrm{g} / \mathrm{ml}$, hal ini dapat diketahui melalui banyaknya jumlah sel yang dihambat pada konsentrasi tersebut yang terlihat pada gambar hasil pengamatan. Hasil analisis probit menunjukkan bahwa pemberian ekstrak etanol buah merah (Pandanus conoideus Lam) memiliki $\mathrm{IC}_{50}$ rata- rata sebesar $0,0149 \mu \mathrm{g} / \mathrm{ml}$, sedangkan nilai $\mathrm{IC}_{80}$ adalah 0,026mg/ml. Hasil tersebut menunjukkan bahwa ekstrak etanol buah merah (Pandanus conoideus Lam) aktif sebagai antimitosis sesuai dengan persyaratan Rahman et al (2001) yaitu suatu bahan dinyatakan aktif jika penghambatan sel terjadi (IC $80-100)$ dicapai pada konsentrasi lebih rendah dari pada $16 \mathrm{mg} / \mathrm{ml}$. Jika dibandingkan dengan vinkristin, efek antimitosis ekstrak etanol buah merah (Pandanus conoideus Lam) jauh lebih rendah, dengannilai $\mathrm{IC}_{80}$ adalah $2,789 \times 10^{-4} \mathrm{mg} / \mathrm{ml}$.

\section{KESIMPULAN}

Berdasarkan hasil penelitian dan pembahasan dapat di simpulkan bahwa ekstrak etanol buah merah (Pandanus conoideus Lam) aktif sebagai antimitosis sel telur Tripneustes gratilla Linn terfertilisasi dengan nilai $\mathrm{IC}_{80}$ adalah $0,026 \mathrm{mg} / \mathrm{ml}$ meskipun potensinya lebih rendah daripada vinkristin dengan nilai $I_{80}$ adalah $2,789 \times 10^{-4} \mathrm{mg} / \mathrm{ml}$ 


\section{DAFTAR PUSTAKA}

Alam, G.(2002). BST sebagai Bioassay dalam Isolasi Senyawa Bioaktif dari Bahan Alam. Majalah Farmasi dan Farmakologi. Vol. 6.No. 2.

Budi, I.M., dan Paimin, F.R. (2005). BuahMerah. PenebarSwadaya. Jakarta.

Campbell, N.A, Reece. J.B, dan Michel, L.G., (1999).Biologi. Edisi V Jilid I, Terjemahan oleh Rahayu llestari. (2002). Erlangga. Jakarta.

Ditjen POM.(1986). Sediaan Galenik. DepKes RI. Jakarta.

Ganiswarna. (2007). Farmakologi dan Terapi. Jilid V. Bagian farmakologi Fakultas Kedokteran UI. Jakarta.

Jasin, M. (1992). Zoologi Invertebrata.Sinar Wijaya. Surabaya.

Junaidi, I.(2007). Kanker Pengenalan, pencegahan dan pengobatan. PT. Buana IImu Populer. Jakarta.

Jong, W, D. (2005). Kanker Apakah itu. Arcan. Jakarta.

Katzung Bertram, G. (2004). Farmakologi Dasar dan Klinik Penerjemah,dan Editor Edisi Indonesia Bagian Farmakologi Fakultas Kedokteran
Universitas Airlangga. Penerbit Salemba Medika. Jakarta.

Kimball, J.W. (1983).Biologi. Edisi V, Jilid 2, Terjemahan oleh Siti Soetarmi Tjitrosomo dan Nawangsari Sugiri, 1992. Erlangga. Jakarta.

$\begin{array}{cr}\text { Mangan, Y.(2005).Cara } & \text { Bijak } \\ \text { Menaklukkan } & \text { Kanker. } \\ \text { AgroMedia } & \text { Pustaka. } \\ \text { Tangerang. } & \end{array}$

Rahman, et al. (2001). Bioassay Techniques For Drug Development. Harwood Academic Publishers.

Sloane, E.(2004). Anatomy and Physiology An Easy Learner. Departemen of Biological Sciences. University of Wisconsin-Milwaukee.

Sumich, J.L and Dudle, G.H. (1982).Laboratory and Field Investigation in Marine Biology.Ed.4. W.M.C Brown Publisher.

Tobo, F. (2001).Buku Pegangan Laboratorium Fitokimia I, Laboratorium Fitokimia., Jurusan Farmasi., Fakultas MIPA. Universitas Hasanuddin. Makassar.

Wahidin, (2011), " Uji antimitosis ekstrak etanoldaun sirsak (Annona muricataLinn) dengan 
Uji Antimitosis Ekstrak Etanol Buah Merah Dengan Metode Penghambatan Pembelahan Sel

metode penghambatan pembelahan sel telur bulu babi (Tripneustes gratilla Linn)". Skripsi, Tidak dipublikasikan.

Fakultas Farmasi Universitas Muslim Indonesia.
Yahya, M. H. (2005). Khasiat dan Manfaat Buah merah. Agromedia Pustaka. Jakarta 